\title{
ANALISIS PREFERENSI KONSUMEN TERHADAP SAYURAN KATUK
}

\author{
W Nahraeni ${ }^{1 \mathrm{a}}$, A Yusdiarti ${ }^{1}$, Elita G Rahayu ${ }^{1}$ \\ ${ }^{1}$ Jurusan Agribisnis, Fakultas Pertanian Universitas Djuanda Bogor \\ Jl. Tol Ciawi No 1 Universitas Djuanda Bogor Kode Pos 16720 \\ ${ }^{a}$ Korespondensi: Wini Nahraeni. Telp: 08129682305; E-mail: winisivadevi@yahoo.com
}

\begin{abstract}
ABSTRAK
Provinsi Jawa Barat merupakan produsen utama sayuran di Indonesia, termasuk sayuran indijenes. Potensi sayuran indijenes tersebut belum dieksploitasi dengan baik, karena kurangnya sosialisasi komponen zat gizi dan zat berkhasiat yang bermanfaat bagi kesehatan, teknik budidaya dan preferensi konsumennya. Penelitan ini bertujuan untuk menganalisis preferensi konsumen terhadap tanaman katuk, tingkat kepentingan dan kinerja atribut sayuran indijenes katuk. Data diambil melalui survey terhadap 50 konsumen di Jakarta dan Bogor. Responden adalah para ibu rumah tangga termasuk didalamnya ibu-ibu PKK (Pembinaan Kesejahteran Keluarga). Pengambilan data dilakukan pada bulan Oktober-November 2016.. Metode analisis menggunakan analisis deskriptif, Multiatribut Fishbein dan Importance and Permormance Analysis (IPA) dengan menggunakan program microsoft office excel 2013 dan SPSS 23. Hasil penelitian menunjukkan bahwa konsumen menginginkan kualitas katuk dengan warna daun hijau muda, ukuran daun sedang, serta jumlah daun/tangkai yang sedikit, tidak memiliki bunga, beraroma sedang dan memiliki jumlah cabang/tangkai yang sedang. Atribut daya simpan dipersepsi konsumen sebagai atribut paling penting, diikuti oleh rasa dan kemudahan dikunyah. Sementara atribut warna, ketersediaan, dan banyaknya jenis olahan katuk dipersepsi konsumen kurang penting. Atribut yang menjadi prioritas utama dalam mengembangkan katuk adalah daya simpan dan kemudahan mengolah. Perlu dilakukan uji organoleptic pada berbagai olahan katuk dalam rangka penelitian lanjutan.
\end{abstract}

Kata Kunci : Sayuran Indijenes, Multiatribut Fishbein, Matrik IPA,

\section{PENDAHULUAN}

Sayuran indijenes (indigenous) adalah spesies sayuran asli pada daerah tertentu atau berasal dari wilayah atau ekosistem tertentu, termasuk spesies atau varietas introduksi yang sudah lama berevolusi dari wilayah geografis lain (Hidayat et al., 2006). Sayuran indijenes merupakan sayuran asli daerah yang telah banyak dibeli dan dikonsumsi sejak zaman dahulu yang telah berkembang lama dan dikenal masyarakat di suatu daerah tertentu (Suryadi dan Kusuma 2004).

Sayuran indijenes merupakan bagian dari keanekaragaman hayati di Indonesia. Namun demikian, sampai sejauh ini perhatian terhadap sayuran indijenes seperti kenikir, pohpohan, paria, kucai, takokak, leunca, kemangi, katuk, dan oyong, masih sangat kurang diminati (Bermawie 2006, Somantri 2006, Kristatit 2010), bahkan cenderung ditinggalkan, baik dari sisi penelitian maupun pengembangannya di tingkat masyarakat (Adiyoga et al. 2002). Penyebab dari kurang berkembangnya kelompok sayuran indijenes diindikasikan oleh atribut kualitas yang dimiliki oleh komoditas tersebut relatif belum sebanding atau sejajar dengan kelompok sayuran prioritas, seperti kentang, cabai merah, dan tomat. Selain itu, nilai ekonomis kelompok sayuran indijenes dalam memasuki pasar juga lebih rendah dibandingkan dengan jenis sayuran utama (Adiyoga et al. 2008).

Provinsi Jawa Barat merupakan produsen utama sayuran di Indonesia, termasuk sayuran indijines. Potensi 
sayuran indijenes tersebut belum dieksploitasi dengan baik, karena kurangnya sosialisasi komponen zat gizi dan zat berkhasiat yang bermanfaat bagi kesehatan, teknik budidaya, dan preferensi konsumennya.

Permintaan beberapa sayuran indijenes terus meningkat seiring dengan peningkatan kesadaran masyarakat mengenai gaya hidup sehat dan peningkatan perkembangan restoran khas Jawa Barat yang menyajikan aneka sayuran indijenes Jenis Sayuran indijenes yang sering dikonsumsi antara lain: daun pakis, daun labu siam, kecipir, leunca, oyong, takokak, paria dan katuk.

Penelitian ini penting dilakukan didasarkan pada fakta bahwa salah satu upaya pemasaran sayuran indijenes yang dapat dilakukan adalah dengan memperbaiki atribut kualitasnya. Selain melalui perbaikan teknis budidaya, perbaikan atribut kualitas juga dapat dilakukan dengan cara mengkaji dan memahami perilaku konsumen (Soetiarso 2010), atau preferensi konsumen terhadap atribut kualitas produk. Dengan diketahuinya atribut yang paling disukai oleh konsumen, maka dapat dijadikan sebagai dasar perbaikan kualitas sayuran indijenes yang pada akhirnya dapat memberikan nilai keunggulan bagi sayuran tersebut

Penelitian ini bertujuan untuk menganalisis preferensi konsumen ibu rumah tangga terhadap sayuran katuk, melihat atribut sayuran indijenes katuk yang paling disukai serta atribut yang paling dominan untuk dikembangkan pada katuk.

\section{BAHAN DAN METODE}

Penelitian dilakukan di daerah Jakarta, serta Kota dan Kabupaten Bogor. Responden adalah para ibu rumah tangga termasuk didalamnya ibu-ibu PKK (Pembinaan Kesejahteran Keluarga). Pengambilan data dilakukan pada bulan Oktober-November 2016. Penelitian ini menggunakan dua jenis data, yaitu data primer dan data sekunder. Data primer bersumber dari wawancara dengan para ibu rumah tangga yang pernah mengkonsumsi sayuran katuk dan data sekunder bersumber dari literatur yang relevan dengan penelitian. Pengumpulan data dilakukan - melalui wawancara langsung kepada konsumen dengan menggunakan kuesoner yang telah ditentukan. Kuisoner yang disebarkan berisi pertanyaan-pertanyaan tentang karakteristik responden antara lain umur, jumlah anggota keluarga, tingkat pendidikan, pekerjaan, dan pengeluaran setiap bulannya.

Analisis data dilakukan dengan menggunakan analisis deskriptif untuk mengidentifikasikan karakteristik responden. Analisis Multiatribut Fishbein digunakan untuk menjawab preferensi konsumen terhadap tingkat kepentingan dan kinerja sayuran indijenes. Untuk melihat sayuran indijenes yang memiliki skor sikap paling tinggi digunakan alat analisis sikap Fishbein (Sumarwan 2004). Analisis ini mengemukakan bahwa sikap terhadap objek tertentu didasarkan pada perangkat kepercayaan dan diberi nilai bobot sebagai nilai evaluasi terhadap atribut tersebut. Rumus multi atribut Fishbein:

Keterangan :

$$
A_{0}={ }_{i=1}^{n} b_{i} e_{i}
$$

Ao = Sikap konsumen terhadap sayuran indijenes

bi = Tingkat Keyakinan konsumen bahwa sayuran-sayuran indijenes memiliki atribut tertentu (atribut ke-i)

ei $=$ dimensi evaluatif konsumen terhadap variabel ke-i yang dimiliki sayuran indijenes

$\mathrm{n}=$ Jumlah atribut yang dimiliki buah sayuran indijenes

Berdasarkan hasil analisis multiatribut Fishbein, kemudian dibuat matrik Importance Performance Analysis 
(IPA) dengan tujuan untuk mengukur hubungan antara harapan konsumen dan prioritas peningkatan kualitas sayuran indijenes yang dikenal sebagai quadrant analysis. Dari hasil analisis tersebut dapat diketahui atribut mana saja yang perlu diperbaiki dan ditingkatkan kualitasnya sesuai dengan harapan konsumen.

\section{HASIL DAN PEMBAHASAN}

\section{Analisis Tingkat kepentingan dan Kinerja Atribut Sayuran Indijenes Katuk}

\section{Analisis Tingkat Kepentingan (ei)}

Tabel 1 dan 2 memperlihatkan tingkat kepentingan terhadap atribut sayuran katuk. Data untuk tingkat kepentingan dalam penelitian ini diperoleh dari wawancara dengan menggunakan kuesioner. Data ordinal menggunakan skala Likert dari 1- 5. Responden diminta untuk memilih atribut dari nilai 1 sangat tidak penting, nilai 2 tidak penting, nilai 3 untuk biasa/netral, nilai 4 untuk penting, dan nilai 5 sangat penting. Atribut yang dianalisis terdiri atas 12 atribut yaitu rasa, ketersediaan, masa ketersediaan, kemudahan mengolah, jenis olahan, harga, kemudahan dikunyah, kandungan zat berkhasiat, warna, ukuran, kandungan zat berbahaya, dan daya simpan

Tabel 1. Evaluasi konsumen (peringkat kepentingan) terhadap atribut sayuran indijenes katuk

\begin{tabular}{|c|c|c|c|c|c|c|c|c|}
\hline \multirow[t]{2}{*}{ No } & \multirow[t]{2}{*}{ Atribut } & \multicolumn{5}{|c|}{$\begin{array}{l}\text { Frekuensi pada setiap } \\
\text { nilai skala }\end{array}$} & \multirow[t]{2}{*}{$\begin{array}{c}\text { Skor } \\
\text { Evaluasi } \\
(e i)\end{array}$} & \multirow[t]{2}{*}{ Peringka } \\
\hline & & 1 & 2 & 3 & 4 & 5 & & \\
\hline 1 & Rasa & 0 & 0 & 7 & 22 & 17 & 4,22 & 2 \\
\hline 2 & Kemudahan memperoleh & 0 & 2 & 22 & 13 & 9 & 3,63 & 9 \\
\hline 3 & Ketersediaan & 0 & 0 & 28 & 10 & 8 & 3,57 & 11 \\
\hline 4 & Kemudahan mengolah & 0 & 1 & 9 & 25 & 11 & 4,00 & 5 \\
\hline 5 & Banyaknya Jenis Olahan & 2 & 5 & 6 & 28 & 5 & 3,63 & 10 \\
\hline 6 & Harga & 0 & 6 & 2 & 26 & 12 & 3,96 & 6 \\
\hline 7 & Kemudahan dikunyah & 2 & 1 & 8 & 12 & 23 & 4,15 & 3 \\
\hline 8 & Kandungan zat berkhasiat & 1 & 7 & 2 & 15 & 21 & 4,04 & 4 \\
\hline 9 & Warna & 10 & 11 & 4 & 12 & 9 & 2,98 & 12 \\
\hline 10 & Ukuran & 3 & 0 & 14 & 22 & 7 & 3,65 & 8 \\
\hline 11 & $\begin{array}{l}\text { Kandungan zat berbahaya bagi } \\
\text { kesehatan }\end{array}$ & 5 & 6 & 2 & 12 & 21 & 3,83 & 7 \\
\hline 12 & Daya simpan & 0 & 1 & 2 & 24 & 19 & 4,33 & 1 \\
\hline
\end{tabular}

Hasil analisis pada Tabel 1 menunjukkan bahwa atribut sayuran indijenes katuk yang dianggap paling penting adalah daya simpan dengan skor 4,33, rasa dengan skor 4,22 dan di peringkat ketiga adalah atribut kemudahan dikunyah. Daya simpan menjadi pertimbangan pertama karena sayuran yang dibeli oleh responden di hari tertentu tidak semuanya diolah di hari tersebut, sehingga responden memilih sayuran yang bisa tahan lebih lama di lemari es untuk diolah di kemudian hari.

Responden memilih sayuran yang mudah dicerna sebagai pertimbangan penting kedua dalam pembelian sayuran indijenes dengan skor 4,22. Sayuran memiliki kandungan dan jenis serat yang berbeda. Beberapa sayuran relatif sulit untuk dilembutkan oleh gigi. Sayuran yang mudah dikunyah menjadi pilihan responden karena lebih disukai baik oleh 
anak-anak maupun orang yang sudah tua yang ada di rumah mereka.

Sementara atribut yang paling tidak mempengaruhi pembelian adalah warna (skor 2,98), ketersediaan (skor 3,57), dan banyaknya jenis olahan (skor 3,63). Jenis olahan sayur diangap paling tidak penting karena beberapa alasan, diantaranya responden tidak merasa berkepentingan dengan jenis olahan yang dapat dibuat dari sayur katuk, karena mayoritas katuk diolah dengan cara yang turun temurun, biasanya hanya disayur bening. Adapun warna dianggap kurang penting karena sebenarnya warna sayuran indijenes yang diperbandingkan tidak terlalu berbeda (rata-rata hijau). Ketersediaan juga menjadi atribut yang tidak terlalu penting karena katuk hampir tersedia setiap hari, sehingga mudah diperoleh.

\section{Analisis Tingkat Kepercayaan (bi)}

Kepercayaan terhadap kinerja sayuran indijenes katuk yang dianalisis tanpa memperhitungkan pembobotan kepentingan kriteria atribut ditampilkan pada Tabel 2. Nilai tingkat kepercayaan didapatkan dari rataan perkalian antara frekuensi dan skala Likert. Semakin besar nilai kepercayaan, maka konsumen semakin percaya atribut tersebut melekat pada sayuran indijenes. Hasil yang diperoleh dari analisis tingkat kepercayaan dan tingkat kepentingan akan menentukan sikap konsumen terhadap sayuran indijenes

Tabel 2. Hasil evaluasi tingkat kepercayaan (bi) terhadap atribut katuk

\begin{tabular}{|c|c|c|c|c|c|c|c|c|}
\hline \multirow[t]{2}{*}{ No } & \multirow[t]{2}{*}{ Atribut } & \multicolumn{5}{|c|}{$\begin{array}{c}\text { Frekuensi pada setiap nilai } \\
\text { skala }\end{array}$} & \multirow[t]{2}{*}{$\begin{array}{c}\text { Skor } \\
\text { Evaluasi } \\
(b i)\end{array}$} & \multirow[t]{2}{*}{ Peringka } \\
\hline & & 1 & 2 & 3 & 4 & 5 & & \\
\hline 1 & Rasa & 1 & 4 & 3 & 21 & 17 & 3,90 & 6 \\
\hline 2 & Kemudahan memperoleh & 16 & 19 & 6 & 3 & 2 & 1,96 & 12 \\
\hline 3 & Ketersediaan & 1 & 9 & 25 & 7 & 4 & 2,96 & 8 \\
\hline 4 & Kemudahan mengolah & 0 & 4 & 31 & 3 & 8 & 3,19 & 7 \\
\hline 5 & Banyaknya Jenis Olahan & 0 & 8 & 35 & 2 & 1 & 2,79 & 9 \\
\hline 6 & Harga & 0 & 2 & 0 & 22 & 22 & 4,21 & 3 \\
\hline 7 & Kemudahan dikunyah & 0 & 0 & 1 & 33 & 12 & 4,06 & 4 \\
\hline 8 & Kandungan zat berkhasiat & 0 & 0 & 0 & 22 & 24 & 4,33 & 1 \\
\hline 9 & Warna & 10 & 20 & 6 & 9 & 1 & 2,27 & 10 \\
\hline 10 & Ukuran & 0 & 0 & 1 & 23 & 22 & 4,27 & 2 \\
\hline 11 & $\begin{array}{l}\text { Kandungan zat berbahaya bagi } \\
\text { kesehatan }\end{array}$ & 0 & 1 & 1 & 31 & 13 & 4,04 & 5 \\
\hline 12 & Daya simpan & 19 & 9 & 7 & 8 & 3 & 2,19 & 11 \\
\hline
\end{tabular}

Tabel 2 menunjukkan tingkat kepercayaan atribut katuk. Secara umum konsumen percaya bahwa katuk yang biasa dibeli sudah baik. Atribut kandungan zat berkhasiat adalah yang paling baik kinerjanya di persepsi konsumen. Atau bisa dikatakan dalam membentuk sikap terhadap katuk, konsumen mempunyai keyakinan (belief) bahwa kandungan zat berkhasiat adalah paling baik dibanding ukuran, harga, dan atribut lainnya. Atribut ukuran dan harga dipercaya sudah baik, namun atribut kemudahan diperoleh, daya simpan dan warna adalah atribut yang kurang baik dipersepsi oleh konsumen. 
Tabel 3. Preferensi konsumen terhadap sayuran daun indijenes

\begin{tabular}{|c|c|c|c|c|c|c|}
\hline \multirow[b]{2}{*}{$\begin{array}{c}\text { Jenis } \\
\text { Sayuran }\end{array}$} & \multicolumn{6}{|c|}{ Atribut } \\
\hline & Warna Daun & $\begin{array}{l}\text { Ukuran } \\
\text { Daun }\end{array}$ & $\begin{array}{c}\text { Jumlah } \\
\text { Daun/Tangkai }\end{array}$ & Bunga & Aroma & $\begin{array}{l}\text { Jumlah } \\
\text { Cabang/ } \\
\text { Tangkai }\end{array}$ \\
\hline \multirow[t]{3}{*}{ Katuk } & $\begin{array}{l}\text { Hijau tua: } \\
10 \% \\
\text { Hijau muda: }\end{array}$ & Kecil : $24 \%$ & sedikit: $52 \%$ & $\begin{array}{l}\text { tidak ada: } \\
14 \%\end{array}$ & $\begin{array}{l}\text { tidak beraroma: } 0 \% \\
\text { beraroma sedang: }\end{array}$ & sedikit: $18 \%$ \\
\hline & $90 \%$ & Sedang: $72 \%$ & sedang: $24 \%$ & ada: $86 \%$ & $100 \%$ & sedang: $70 \%$ \\
\hline & & Besar:4\% & banyak:24\% & & langu: $0 \%$ & banyak: $12 \%$ \\
\hline
\end{tabular}

\section{Analisis Sikap Konsumen (Ao) A Multi Atribut Fishbein}

Tabel 4 memperlihatkan sikap konsumen terhadap katuk. Baris pertama Tabel 4 memperlihatkan bahwa responden (konsumen) memberi angka rata-rata 3,90 pada belief/evaluasi kepercayaan. Hal ini berarti konsumen menganggap rasa sudah baik. Nilai untuk evaluation/evaluasi konsumen memberi angka rata-rata 4,22 yang berarti atribut rasa adalah baik dalam mempertimbangkan untuk membeli katuk. Oleh karena angka evaluation lebih tinggi dari angka belief, maka sebenarnya konsumen menilai rasa katuk tersebut masih di bawah harapannya. Secara umum angka evaluation lebih tinggi dari angka belief, maka sebenarnya konsumen menilai atribut tersebut katuk tersebut masih di bawah harapannya, kecuali untuk atribut harga, kandungan zat berkhasiat, ukuran dan keamanan dari zat berbahaya, konsumen menilai atribut tersebut di atas harapannya.

Tabel 4. Sikap konsumen terhadap Katuk

\begin{tabular}{|c|c|c|c|c|}
\hline \multirow[b]{2}{*}{ No } & \multirow[b]{2}{*}{ Atribut } & \multicolumn{2}{|c|}{$\begin{array}{l}\text { Sikap Evaluasi } \\
\text { Kepentingan }\end{array}$} & \multirow{2}{*}{$\begin{array}{c}\text { Sikap } \\
\text { konsumen } \\
A o(e i X \\
b i)\end{array}$} \\
\hline & & (ei) & $(b i)$ & \\
\hline 1 & Rasa & 4.22 & 3.90 & 16,430 \\
\hline 2 & Kemudahan memperoleh & 3.63 & 1.96 & 7,110 \\
\hline 3 & Ketersediaan & 3.57 & 2.96 & 10,547 \\
\hline 4 & Kemudahan mengolah & 4.00 & 3.19 & 12,750 \\
\hline 5 & Banyaknya Jenis Olahan & 3.63 & 2.79 & 10,135 \\
\hline 6 & Harga & 3.96 & 4.21 & 16,650 \\
\hline 7 & Kemudahan dikunyah & 4.15 & 4.06 & 16,868 \\
\hline 8 & Kandungan zat berkhasiat & 4.04 & 4.33 & 17,522 \\
\hline 9 & Warna & 2.98 & 2.27 & 6,763 \\
\hline 10 & Ukuran & 3.65 & 4.27 & 15,598 \\
\hline 11 & Kandungan zat berbahaya bagi kesehatan & 3.83 & 4.04 & 15,464 \\
\hline \multirow[t]{2}{*}{12} & Daya simpan & 4.33 & 2.19 & 9,463 \\
\hline & & $\sum e i X b i$ & & 155,300 \\
\hline
\end{tabular}

Nilai rata-rata dari skor tingkat kepentingan dan skor tingkat kinerja/harapan responden terhadap sayuran indijenes katuk selanjutnya diplotkan pada diagram Cartesius yang terdiri atas empat kuadran seperti terlihat pada Gambar 1 dan Tabel 4. Kuadran I merupakan kuadran dengan prioritas utama, kuadran II pertahankan prestasi, kuadran II prioritas rendah, dan kuadran 
IV berlebihan. Atribut pada diagram Cartesius yaitu (1) rasa, (2) kemudahan memperoleh, (3) ketersediaan, (4) kemudahan mengolah, (5) banyaknya jenis olahan, (6) harga, (7) kemudahan dikunyah, (8) kandungan zat berkhasiat, (9) warna, (10) ukuran, (11) kandungan zat berbahaya bagi kesehatan, dan (12) daya simpan..

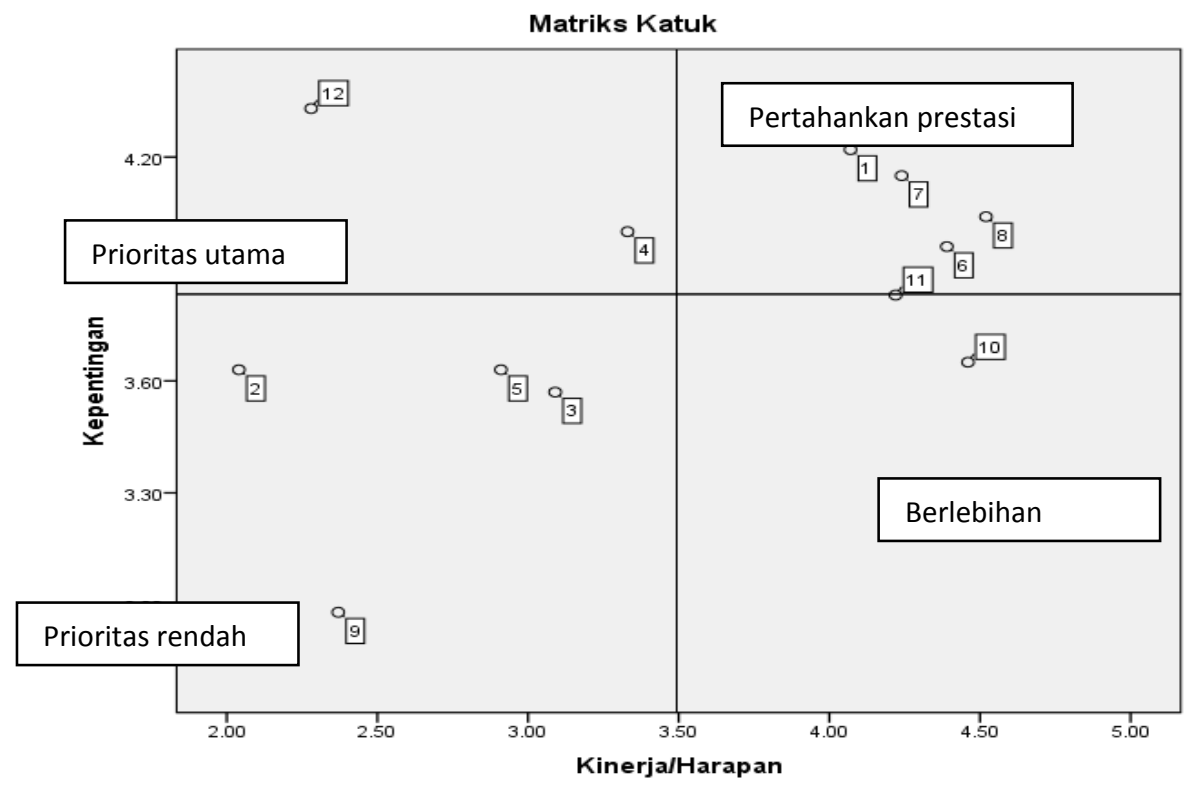

Tabel 4 menunjukkan hasil important and performance matrix responden konsumen katuk. Daya simpan (12) dan kemudahan mengolah (4) merupakan atribut yang dianggap penting namun kinerjanya tidak memuaskan (kuadran I). Atribut rasa, harga, kemudahan dikunyah, kandungan zat berkhasiat, keamanan dari zat berbahaya merupakan atribut yang dianggap penting dan kinerjanya dinilai telah memuaskan oleh semua konsumen (kuadran II). Kemudahan memperoleh katuk, ketersediaan, banyaknya jenis olahan, dan warna merupakan atribut yang tingkat kepentingan dan kinerjanya dinilai rendah karena berada di Kuadran III. Ukuran merupakan atribut yang dinilai berlebihan (ini termasuk kuadran IV ).

Tabel 4. Hasil Important and Performance Matrix Responden Katuk

\begin{tabular}{llll}
\hline Kuadran I & Kuadran II & Kuadran III & Kuadran IV \\
\hline $\begin{array}{l}\text { Kemudahan } \\
\text { mengolah (4) }\end{array}$ & Rasa (1) & $\begin{array}{l}\text { Kemudahan } \\
\text { memperoleh (2) }\end{array}$ & Ukuran (10) \\
$\begin{array}{l}\text { Daya simpan } \\
(12)\end{array}$ & Harga (6) & Ketersediaan (3) & \\
& $\begin{array}{l}\text { Kemudahan dikunyah } \\
(7)\end{array}$ & $\begin{array}{l}\text { Banyaknya jenis } \\
\text { olahan (5) }\end{array}$ & \\
& $\begin{array}{l}\text { Kandungan zat } \\
\text { berkhasiat (8) } \\
\text { Kandungan zat } \\
\text { berbahaya bagi } \\
\text { kesehatan (11) }\end{array}$ & Warna (9) & \\
& & & \\
\hline
\end{tabular}




\section{KESIMPULAN DAN SARAN}

\section{Kesimpulan}

Hasil penelitian menunjukan bahwa:

1. Preferensi konsumen dalam memilih/membeli katuk adalah warna daun lebih hijau muda, dengan ukuran daun sedang, serta jumlah daun/tangkai yang sedang, tidak memiliki bunga, beraroma sedang dan memiliki jumlah cabang/tangkai yang sedang.

2. Atribut daya simpan dipersepsi konsumen sebagai atribut paling penting, diikuti oleh rasa dan kemudahan dikunyah. Sementara atribut warna, ketersediaan, dan banyaknya jenis olahan katuk dipersepsi konsumen kurang penting.

3. Atribut yang menjadi prioritas utama dalam mengembangkan katuk adalah daya simpan dan kemudahan mengolah

\section{Implikasi Kebijakan}

Untuk penelitian lanjutan sebaiknya dilakukan analisis preferensi konsumen bersamaan dengan uji organoleptic pada katuk.

\section{DAFTAR PUSTAKA}

Adiyoga, W., R. M. Ameriana, dan T. A. Soetiarso. (2008). Segmentasi Pasar dan Pemetaan Persepsi Atribut Produk Beberapa Jenis Sayuran Minor (Under-utilized). Jurnal Hort. 18(4):466-476.

Adiyoga, W., R. Suherman, Nurhartuti, A. Hidayat, M. Ameriana, T.A. Soetiarso, Suryadi, dan Koesdibyo. (2002). Penggalian Potensi Ekonomis Pemanfaatan Sayuran
Indigenous. Laporan Akhir APBN 2002. Bandung: Balai Penelitian Tanaman Sayuran, Pusat Penelitian dan Pengembangan Hortikultura, Badan Penelitian dan Pengembangan Pertanian.

Bermawie, N. (2006). Sayuran Indigenous sebagai Sumber Nutrisi dan Obatobatan Keluarga. Makalah Disampaikan pada Pelatihan Promosi Pemanfaatan Sayuran Indigenous untuk Peningkatan Nutrisi Keluarga melalui Kebun Pekarangan. Jakarta 17-19 April 2006.

Engel, J.F., et. al. (1994). Consumer Behavior. Diterjemahkan oleh F.X. Budiyanto. Jakarta: Binarupa Aksara.

Hidayat, IM, Kirana R, Gaswanto R, Kusmana. 2006. Petunjuk Teknis Budidaya dan Produksi Beberapa Sayuran Indigenous. Balitsa. Puslitbanghorti. Balitbangtan

Somantri. 2006. Pentingnya Melestraikan Syuran Indigenous (Indijenes). Makalah disampaikan pada pelatihan “ Promosi Pemanfaatan Sayuran Indigenous untuk Peningkatan Nutrisi Keluarga melalui Kebun Pekarangan. Jakarta 17-19 April 2006. $6 \mathrm{Hlm}$

Soetiarso, T.A. (2010). Preferensi Konsumen terhadap Atribut Kualitas Empat Jenis Sayuran Minor. J. Hort. 20(4):398-407.

Suryadi dan Kusuma. (2004). Mengenal Sayuran Indijenes. Bandung: Balai Penelitian Tanaman Sayuran. 